\title{
Are the four Baconian idols still alive in demography?
}

\author{
DANIEL COURGEAU ${ }^{1}$ \\ JAKUB BIJAK ${ }^{2}$ \\ ROBERT FRANCK ${ }^{3}$ \\ ERIC SILVERMAN ${ }^{2}$
}

Résumé

Cet article examine les quatre sortes d'idoles qui selon le Novum Organon de Bacon (1620) affectent l'esprit humain. II s'agit des idoles de la Tribu - qui résultent de la croyance "que le sens humain est la mesure des choses»; des idoles de la caverne - qui sont propres à chacun de nous; des idoles du forum - «qui prennent naissance dans le commerce et la communauté des hommes», et des idoles du théâtre «introduites dans l'esprit par les divers systèmes des philosophes et les mauvaises méthodes de démonstration». Nous examinons si ces idoles sont toujours présentes dans les sciences sociales contemporaines, et examinons plusieurs exemples affectant la démographie - la génétique du comportement, la théorie postmoderne, I'héréditarisme et l'herméneutique moderne. L'analyse de ces exemples suggère fortement que la démographie doit rester fidèle à la méthode scientifique lorsqu'elle recourt à de nouvelles approches et inspirations.

\section{Mots-clés}

Épistémologie, démographie, sciences sociales, génétique, méthodes.

\section{Summary}

In this paper, we examine the four Idols that beset human minds according to Francis Bacon's Novum Organum (1620). These are: Idols of the Tribe - false assertions resulting from the belief that "the sense of man is the measure of things»; Idols of the Cave - peculiar to the individual people; Idols of the Market Place - resulting from "the intercourse and association of men with each other", and Idols of the Theatre - stemming from «dogmas of philosophies and... wrong laws of demonstration». We aim to see if these Idols are still alive in contemporary population sciences, and look at several examples from the fringes of demography - behaviour genetics, postmodern theory, hereditarianism, and modern hermeneutics. The ana-

\footnotetext{
1. INED.

2. University of Southampton.

3. Université catholique de Louvain.
} 
lysis of these examples strongly suggests that demography needs to remain faithful to the scientific method whilst looking for new insights and inspirations.

\section{Key words}

Epistemology, demography, social sciences, genetics, methods.

\section{Introduction}

Francis Bacon wrote the Novum Organum (1620) in order to elaborate an inductive method in opposition to the Organon, the name given by Aristotle's disciples to the set of his six works on logic. He contrasted his new approach to the standard one at the time, saying:

«There are and can be only two ways of searching into and discovering truth. The one flies from the senses and particulars to the most general axioms, and from these principles, the truth of which it takes for settled and immovable, proceeds to judgement and to the discovery of middle axioms. And this way is now in fashion. The other derives from the senses and particulars, rising by a gradual and unbroken ascent, so that it arrives at the most general axioms last of all. This is the true way, but as yet untried» (Book One, XIX).

During the 17th century, this new, inductive, way of inference was followed as well in the natural sciences: in astronomy in Newton's volume on Philosophiae naturalis principia mathematica $(1687)^{4}$, in the theory of probability by Pascal $(1654)^{5}$, mainly applied during this century to games or population sciences, and by Graunt in population sciences, with his Bills on Mortality (1662) ${ }^{6}$. We must say here how his notion of induction was different from the version that is familiar to us nowadays. This method consists of discovering the principles of natural or social properties by way of experimentation and observation, in the sense that without these principles the properties observed would be different (Franck, 2002). In contrast Mill (1843) and his followers consider under this term only the generalization from particular facts, which is entirely different.

The first way was more precisely characterized by Bacon through the metaphors of the four Idols which he called: Idols of the Tribe; Idols of

4. The reader may be interested to see how Newton applied Bacon's views, in Ducheyne (2005).

5. Pascal developed this new approach in his correspondence with Fermat in 1654 (Pascal, 1922).

6. Graunt clearly referred to Bacon in his Epistle dedicated to the honourable Sir Robert Moray. 
the Cave; Idols of the Market Place; and Idols of the Theatre. His book gave many examples of these four kinds of Idols, so that they may be clearly understood.

We have already shown how during the following centuries, paradigm change in demography was largely in the line of Bacon's second way (Courgeau, 2012; Bijak et al., 2014) and we think that his inductive approach is still the best way to achieve the objectives of population sciences. This is why now, over 350 years after Graunt's seminal work, we would like to examine if the first way is still followed in some particular areas of demography and to show what particular interests and aims may be involved.

This paper is a critical essay and should be treated as such. The main motivation behind it consists in the presence of epistemological problems at the fringes of contemporary population studies. Hence, in this paper we will examine each of the Idols and try to see if they are still alive in the context of demography, and if so, what form they may take currently. However, for the sake of the transparency of presentation, we will not present here an exhaustive view of such ideologies, but only some illustrative examples of their use. The choice of examples is necessarily subjective, but we hope that they will nonetheless help illuminate some of the challenges facing the 21st century demography, increase self-awareness of our discipline, and help avoid some of the Idols in the future.

\section{Idols of the Tribe (Idola tribus)}

Let us see how Bacon characterized these first Idols. In Bacon's view, they rest upon the «false assertion that the sense of man is the measure of things» (Book One, XLI):

«The human understanding is of its own nature prone to suppose the existence of more order and regularity in the world that it finds. And though there may be many things in nature which are singular and unmatched, yet he devises for them parallels and conjugates and relatives which do not exist» (Book One, XLV).

He gave for natural sciences the example of the «fiction that all celestial bodies move in perfect circles» (idem) and for social sciences the example of astrology, which is always followed by many men but no longer considered a scientific matter. 
For social sciences these idols are more precisely what the perceptions of our mind permit us to think. Every person knows what a birth is, or a death or a move in space - but it is more difficult to understand what lay behind these concepts of fertility, mortality and migration, which form the basis of population sciences. However, these individual events, which are universally human, may prevent any scientific thinking about them. When they appear today in the press, the media, etc., they are mainly being considered as personal events, and not as occurring to a statistical individual. Such events, often selected for their uniqueness and for how strongly they impact on the minds of the readers or viewers, are not representative of the processes that underlie them.

We will give now another recent example: behavioural genetics (or: behaviour genetics), used by a number of researchers who publish papers on this topic in major demographic journals (Morgan, King, 2001; Rodgers et al., 2001a; Miller et al., 2010). It is also used in a great number of social sciences, such as educational science, medicine, physiology, psychiatry, psychology, sociology, etc. (Plomin et al., 2012). These researchers use this method to study not only demographic traits, such as fertility, partnership formation, longevity, infant and childhood mortality, divorce, etc., but also every kind of human trait, such as intelligence, personality, smoking, homosexuality, femininity, obesity, aggression, etc. The two central points of these studies are (1) the claim that there is a genetic component in behavioural traits, and (2) that the contribution of this component to the variance of the traits in the population can be measured (Vetta, Courgeau, 2003, p. 402).

The answer to the first point could be «yes», as it might be possible to find some genetic background for any human characteristic. To answer the second point, however, we have to see if it is possible to split up an observed behaviour into a genetic component and an environmental one. We will show here how such an approach, which goes back to what was called «biometry» in the work of Galton (1865), is devising, in the words of Bacon, «parallels, conjugates and relatives which do not exist» (idem). Let us see in more detail the hypotheses on which it is based.

First, it is based on assumptions made a long time ago by Fisher (1918). They can be given, under more contemporary terms, as follows: there exist polygenes, that (i) act positively, (ii) segregate independently and (iii) whose number may be considered as infinite; next, (iv) the environment is independent of genes and random, and (v) the population is in Hardy-Weinberg equilibrium, e.g. there are no changes in gene or genotype frequencies from one generation to the next (Vetta, Courgeau, 2003, p. 405). With these assumptions Fisher was able to give an addi- 
tive decomposition of the variance of a given trait into different genetic effects (for more details, see Visscher et al., 2008). Notably, as we discuss later, Vetta (1976) has shown Fisher's formulae to be incorrect.

Also, it is based on the concept of heritability, due to Lush (1936), who devised it based on the experiments on plants, even though himself was concerned that the concept may be misused ${ }^{7}$. Formally, the heritability of a trait within a population is «a ratio of variances, specifically as the proportion of total variance in a population for a particular measurement, taken at a particular time or age that is attributable to variation in additive genetic or total genetic values» (Visscher et al., 2008, p. 255). The latter is usually referred to as «heritability in the broad sense», and denoted by $H^{2}$, whereas the former is labelled as «heritability in the narrow sense», and denoted by $h^{2}$ (idem).

At this time these concepts were used by animal and plant breeders, and behaviour genetics began to be used to study human behavioural traits, particularly twin studies at the beginning of the seventies, with the work of Jinks and Fulker (1970). They used Fisher's formulae - the incorrect one - to show that, even if there is a dependence and interaction between phenotypic and environment variances, it is always possible to consider the effect of genes and the effect of environment separately in an additive model.

However, these assumptions (axioms) were not obtained through a systematic observation of certain properties of genes, as at this time there was no possible way to verify their truth, but they were mainly counterfactual ones, too quickly drawn from some existing statistics and afterwards considered settled truths.

Later, we see that with the discovery of the molecular structure of DNA by Watson and Crick in 1953 and the analysis of the human genome with only $20^{\prime} 774$ protein-coding genes ${ }^{8}$, the hypothesis of a very great number of polygenes for a given trait may no longer be tenable: given the vast number of proteins in the human body, the DNA alone cannot provide a blueprint for their structure. Also, as all genes on a chromosome segregate together, the hypothesis that genes segregate independently is not correct and the additivity of effects is destroyed.

We can also show that the hypothesis relating to the additivity of gene and environment has no scientific content, and that Hardy-Weinberg

7. The authors are grateful to Atam Vetta for pointing this out.

8. The evaluation is provided e.g. in http://www.ensembl.org/Homo_sapiens/ Info/StatsTable (as of 1/04/2014). 
equilibrium for humans has no reason to be verified, as it means that there are no migrations, no assortative mating, no mutation nor selection of any type. Finally, Vetta (1976) showed that Fisher's (1918) kinship correlation formulae under non-random, assortative mating are wrong and that some formulae of Jinks and Fulker (1970) are also wrong, making their method useless. For a more detailed demonstration of all these incorrect assumptions you can see in the social sciences: Sarkar (1998), Capron, Vetta (2001), Gottlieb (2001), etc. and in demography more particularly: Vetta, Courgeau (2003), Courgeau, Vetta (2006), etc. As Gottlieb (2001) said:

«It is now known that both genes and environment are involved in all traits and that it is not possible to specify their respective weighting or quantitative influence on any trait. [...] this has been a hard-won scientific insight that had not yet percolated to the mass of humanity» (p. 6'121).

We can also conclude that the use of the concept of heritability linked to Fisher's assumptions leads to a dead end (Jacquard, 1983).

However the behavioural geneticists remained silent about these criticisms and continued making these same errors - even the entrance into the genomic era did not reduce their audience. Rodgers et al. (2001b) wrote about human fertility:

«In the future, the important theoretical questions in this arena may well emerge from the human genome project» (p. 187).

Again many studies were published during the last years using classical twin studies ${ }^{9}$ and genomic methods simultaneously (Van Dongen et al., 2012).

For example, genome-wide association studies (GWASs), that define genomic regions associated with some traits or complex diseases, have during the past 7 years identified «around 2'000 robust associations with more than 300 complex diseases and traits» (Manolio, 2013, p. 549). These studies were designed to show the links existing between DNA and human traits and behaviours. However, as Manolio explained, the «initial euphoria [...] has dimmed somewhat with the recognition that GWAS-defined loci explain only a very small proportion of different traits' heritability, [and] they have met considerable skepticism regarding their clinical applicability» (idem). Thus, we believe that this skepticism may be explained by the blind alley of heritability.

9. Twin models may be extended for other relatives, such as parents, siblings, spouses or offspring. 
More recently, software called genome-wide complex trait analysis (GCTA) was developed to deal with «missing heritability» (Yang et al., 2011). However, as Turkheimer has put it on his blog:

«GCTA is more like a twin study than it is like gene-finding. SNP arrays are used to define pairwise genomic similarity among 'unrelated' individuals, and then genomic similarity is compared to phenotypic similarity. So yes, the heritability that was detected via quantitative genetics exists down in the SNPs somewhere, but where else would it have been?» ${ }^{10}$.

The final nail in behavioural genetics' coffin is given by Charney (2012). He clearly shows that:

«The cumulative evidence of recent discoveries in genetics and epigenetics calls into question the validity of two classes of methodologies that are central to the discipline [behaviour genetics]: twin, family, and adoption studies, which are used to derive heritability estimates, and gene association studies, which include both genome-wide and candidate-gene association studies» (p. 332).

Charney's paper was followed by a very large number of peer commentaries from different social sciences, and by authors' responses. Even though this shows an increasing agreement against the use of behavioural genetics, a number of commentators remain convinced of the usefulness of behavioural genetic methods.

We hope that we have shown clearly that behavioural genetics supposes the existence of more order and regularity in human heredity that it finds: additivity of effects, independence between environment and genes, randomness of the environment, etc. All these regularities are fallacious and a real scientific approach to this question may only be found while using the scientific results of molecular and genomic sciences.

We will see later, in the part concerned with the Idols of the Theatre, that this attitude may be linked also to more political motivations with the notions of eugenics and hereditarianism.

\section{Idols of the Cave (Idola Specus)}

Let us now see how Bacon characterized this second kind of Idol. He proposed that the individual may construct an entire system, with reference to a few observations and ideas. He gave the example of chemists which «out of few experiments of the furnace, have built up a fantastic

10. Quoted after: http://ericturkheimer.blogspot.fr, entry from 13 February 2013 (as of 1/04/2014). 
philosophy, framed with reference to a few things» (Book One, LIV). More generally he presents those using these idols as follows:

«There are found some minds given to an extreme admiration of antiquity, other to an extreme love and appetite for novelty; but few so duly tempered that they can hold the mean, neither carping at was had been well laid down by the ancient, nor despising what is well introduced by the moderns» (Book One, LVI).

Such an appetite for novelty with reference to few things can be found nowadays in postmodern theory, which tries to reject any real scientific or objective approach, putting art, science and religion on an equal footing. Simultaneously, many perspectives from the past have re-emerged with new relevance, so that such an approach cumulates the appetite for novelty with the admiration of antiquity, such as Gnosticism and the major esoteric traditions. Postmodernism rejects all reference to a long tradition of scientific thinking which stays between antique and more recent ideas and considers everything as a social construction.

Before looking more precisely at its application to demography, let us first see its more general applications trying to link the three aspects of human condition, as in the paper written by Latour: How to be iconophilic in art, science and religion (1998).

As long as postmodernism remained on an artistic basis (architecture, literature, music) or on a religious one, it is out of our field. However, recently Derrida, Jameson, Lacan, Lyotard, etc., introduced scientific terms in their arguments and even rejected true scientific thinking like the second way proposed by Bacon. Such an attitude makes them directly enter in the field of this paper. For example, Latour (1998) said:

\begin{abstract}
«When science was obsessed by what happened in the Mind or what was the case in the World, the distance with arts, especially the visual arts, was at its maximum. But when science began to be seen as a mediating visual activity, then the visual arts offered a fabulous resource; they had always thought of themselves in terms of mediation and never bothered enormously about the representing Mind nor the represented World, which they took as useful but not substantial vanishing points» (p. 422).
\end{abstract}

This view of scientific research introduces a construction of the mind that is 'fallible and relative', not only in art and religion, but also in science, with only local beliefs being put in evidence.

This approach inspired the notorious Sokal hoax, an article (1996) collecting a number of the - in Sokal's own words ${ }^{11}$ - «silliest quotations

11. Quoted after: http://www.physics.nyu.edu/sokal/noretta.html (as of 1/04/ 2014). 
[...] about mathematics and physics» from postmodernist authors, in an apparently serious paper. Sokal and Bricmont (1997) repudiate the idea that science amounts to social construction:

«We show that famous intellectuals such as Lacan, Kristeva, Irigary, Baudrillard, and Deleuze have repeatedly abused scientific concepts and terminology: either using scientific ideas totally out of context, without giving the slightest justification - note that we are not against extrapolating concepts made from one field to another, but only against extrapolations made without argument - or throwing around scientific jargon in front of their non-scientist readers without any regard for its relevance of even its meaning» (p. X).

Even if such an attack raised important reactions of academics and the press, it did not stop the extension of postmodern theory in demographic literature.

One of the first attempts to introduce this theory in demography is in van de Kaa's (1998) paper, Postmodern fertility preferences: from changing value orientation to new behaviour. Van de Kaa recognizes that, the term "postmodern" has not been included in the demographic discourse before. In his view, the main reason for this rejection may be because of the elusive character of this concept. In view of a more serious use of it, he conceptualizes it as a world view (Weltanschauung) that he ascertains by looking at a wide range of attitudes. He developed 11 scales of what he called «bourgeois» postmodernity, which cover such issues as «religiosity, requirements for a successful marriage, gender roles and socialization» (p.21). According to van de Kaa, the group of people meeting the criteria of a «true» postmodernist is small but is higher for younger generations than for older, as expected.

Then, van de Kaa tries to explore the relationship between the levels of «bourgeois» postmodernity in the industrial countries, measured by World Value Surveys, and the marital and fertility scores in the second demographic transition. A regression analysis of the postmodernity indicator against the fertility scores suggests low correlation $(R=0.318$, not significant), higher for the one against the marital scores $(R=0.548$, significant). Needless to say, the usual caveat about correlation not implying causal relationships remains in force. More detailed analysis, in particular using the near concept of postmaterialism ${ }^{12}$, most largely used in social sciences but less extensively than the concept of postmodernism, led him to say:

12. Such a concept characterises the shift from «materialist values (economic and physical security) to... postmaterialist values (individual self-expression and quality of life)» (van de Kaa, 1998, p. 8). 
«One could postulate here that, as the process of postmodernization continues, postmaterialists might find it easier to combine childbearing with other activities and might then be able to match or exceed the numbers of children born to materialists. However, as yet support for that pervasive thesis is not strong» (van de Kaa, 1998, p. 32).

Finally, van de Kaa stated that, even if such an analysis did not lead for the moment to very clear results, a «clever way of anticipating developments probably is to envisage the options of the postmodern avant-garde will dream up and select» (p. 36).

In her comments to this paper, Bacharach (2001) wonders whether the need of a precise conceptualization for the concept of postmodernism is compatible with the essence of postmodern ideas and thoughts:

«However, his [van de Kaa's] attempt to operationalize even these limited meanings using extant survey data proves fraught with difficulty, and arguably transforms the idea of postmodernism into variables that would not be recognized or accepted by postmodernists» (p. 332).

Bacharach also stated that, as was shown in more detailed studies of attitudes towards family issues (Moors, Palomba, 1995), family values cannot be compared with postmodern values. This leads to more complex tensions between the two sets of values that a postmodernist approach alone would not be able to answer.

A more complete presentation of Demography in the age of the postmodern was published a little later (2003) by Riley and McCarty. This volume takes a very short-sighted view of the history of demography distinguishing only two main periods: a modernist approach and a postmodernist one. Even its authors think that postmodernism has rarely been used in the past and that demography was mainly remaining in the modern era.

First, they appear to be unaware of 250 years of demographic thinking from Graunt (1662) to the early twentieth century with major thinkers in the domain such as Huygens, Euler, Laplace, etc. For them demography is mainly a modern science born at the beginning of the 20th century and remaining in great demand by a wide variety of clients, mainly political ones:

«Because funding has been secure and because it has a ready market for the use of its findings, demography has had less reason to question the very nature and premises of the field itself» (Riley, McCarty, 2003, p. 82).

Again, they seem to be unaware of the important changes in paradigm that occurred from the end of World War II: from a cross-sectional, to a cohort, to an event-history and to a multilevel paradigm (Courgeau, 
2007). They mainly consider, this time with reason, the shortcomings of the demographic transition theory.

Riley and McCarty (2003) do not clearly say that demography is now entering in the era of postmodernism but only «suggest that postmodern perspectives have already entered the field of demography, even if they are not named as such» (p. 158). However their book is a defence for its larger use in demography and they present a number of examples of studies that they think perform particularly well in highlighting the usefulness of a postmodern approach.

One of their points is «a move away from universal perspectives and a focus on the local» (Riley, McCarty, 2003, p. 120). However, an important movement towards detailed and local surveys has been present in demography for more than forty years. Examples include a survey on local networks in a French commune (Courgeau, 1972) or a detailed survey about demographic, professional and migratory experiences (Courgeau, 1985). This interest, which gives «attention to inequalities and their influences», does not simultaneously put aside a «focus on better or exact measurement» (Riley, McCarty, idem).

Finally, the definition of Lyotard $(1979,1984)$, describing postmodernism as «incredulity about metanarratives» (passim), which has already been criticized by Sokal (1996) from the point of view of physics, seems to us similarly open to criticism from social sciences. It is sufficient in our opinion to oppose this incredulity to the progress of social sciences and demography in recent years.

We will conclude this part by saying that the Idols of the cave, always running against demography, did not give rise to an important postmodern movement in these sciences, but only some wavelets which did not reach its core.

\section{Idols of the Market Place (Idola fori)}

For Bacon, these idols are «formed by the intercourse and association of men with each other» (Book One, XLIII). He said about them:

«But the Idols of the Market Place are the most troublesome of all - idols which have crept into the understanding through the alliance of words and names. For men believe that their reason governs the world; but it is also true that words react on the understanding; and this it is that has rendered philosophy and the sciences sophistical and inactive» (Book One, LIX). 
He gave different examples of such idols as they were at his time, but did not include in them political scientific debates that have now become much more important than in Bacon's times, when political power was largely in the hands of absolute monarchs.

The political debates of the present day also use «names of things which do not exist, or... exist, but yet confused and ill defined, and hastily and irregularly derived from realities» (Book One, LX). The political motivation is their main purpose, "formed by the intercourse and association of men» (Book One, XLIII), and it is sustained by false claims of scientific validity.

The example we will treat here is eugenics, now referred to as hereditarianism, which is often associated with behavioural genetics, but is mainly a political tool. As for postmodernism, we will first develop its main general aims, before looking in more detail its approach to the demographic field.

Though it was already present in the work of Galton from his book on Hereditary genius (1869), he fully introduced this concept in 1883 under the denomination of 'eugenics', and this was very influential in the early 20th century. It has been clearly defined by Galton in 1904 as:

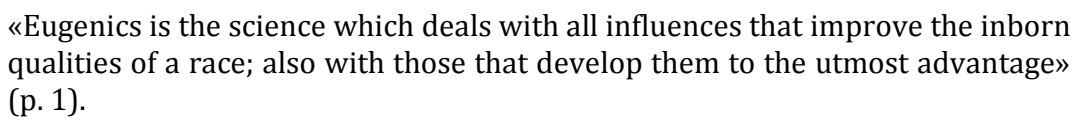

From this definition, Galton considers eugenics a science. Such a science however introduces another concept: improving the qualities of the race.

Even though Darwin, Galton's half-cousin, agreed in principle that intellectual activity can be inherited, he was not entirely in agreement with Galton's ideas on eugenics. He wrote to him in January 1873 about the eugenic register he was promoting (cited after: Galton, Galton 1998, p. 100):

$$
\begin{aligned}
& \text { "... the greatest difficulty I think would be in deciding who deserved to be on } \\
& \text { the register. How few are above mediocrity in health, strength, morals and in- } \\
& \text { tellect; and how difficult to judge on these latter heads». }
\end{aligned}
$$

Still, Galton did indeed «draw up a tentative scale of how to estimate the 'worth' of persons, corresponding to the virtues and values of Victorian England» (idem), based mainly on the predominant political views of the time. The scale was largely based on the combination of social class and «merit», with the highest rank given to «Ministers of State, Heads of Departments, Bishops, Judges, Commanders and Admirals in Chief, Governors of Colonies and other appointments» (idem). 
As further noted by Galton and Galton (1998), these ideas were followed up in various countries: already by 1931, sterilization laws had been adopted in 27 states in the US. During the Nazi period in Germany, between 1933 and 1945, German biologists, anthropologists and geneticists actively invoked eugenic principles to justify Nazi racial policies (idem). Later, the label 'eugenics' was rejected after the end of World War II, having become associated with Nazi Germany, and was replaced by «hereditarianism», a more neutral term, which encompassed many of the eugenicist ideas.

We will show now how these principles were applied in a great number of so-called demographic studies.

It is very interesting to note that Galton (1873) undertook the first systematic demographic study of differential fertility, using extracts from census returns about «1'000 'families' of factory hands at Coventry [and] 1'000 families of agricultural labourers in rural parishes of Warwickshire» (idem, pp. 20-21). His purpose was to show that:

«... those whose breed is the most valuable to our nation are attracted from the country to our towns. If, then, residence in towns seriously interferes with the maintenance of their race, we should expect the breed of Englishmen, so far as that influence is concerned, to steadily deteriorate» (p. 19).

He found that «the rate of supply in towns to the next adult generation is only 77 percent, or, say three quarters of that in the country» (idem), showing that his fear is verified. However, if his study showed a lower fertility of «artisan townsfolk» compared with «labouring people who live in healthy country districts» (idem, p. 23), this did not mean that the English «race» deteriorated, as Galton pretended.

A detailed study from Soloway (1990) during the beginning of the 20th century shows clearly the link between fertility and the question of «race quality»:
«Inverse correlations between fertility and social status focused public atten- tion upon the highly subjective and emotional question of 'race quality' and provoked alarming predictions that Britain would also be swamped by the so- cially and, if eugenicists were correct, genetically 'unfit'» (p. XI).

This prospect of «race suicide» was feared in all European and North American countries and a number of demographic studies at the time were very often linked to eugenics.

In his paper on links between eugenics and interwar demography, Ramsden (2003) highlights the connections existing between the International Union for the Scientific Investigation of Population Problems (IUSIPP), founded in 1928, renamed in 1947 as the International Union 
for the Scientific Study of Population (IUSSP), and the eugenic groups. The eugenicists' influence was great at the time when IUSIPP was founded. The Union's first president, the American biologist Pearl, even though he emphasized science over policy, tended to promote his own approach. As noted by Ramsden (2003):

«Pearl was determined to establish a biometric approach to population study and eugenics - an approach that had been lacking in the United States, given American eugenicists' predilections for a simplistic interpretation of Mendelian theory» (p. 554).

This approach was also followed by Corrado Gini, president of Italy's Central Statistical Institute and vice-president of the IUSIPP, who was supportive of Mussolini's Fascist regime (idem). The next IUSIPP conference, held in Berlin in 1935, was also highly controversial, as there «German biologists promoted extreme theories and programs of racial hygiene» (Ramsden, 2003, p.557). This happened despite AngloAmerican attempts to create an alternative through establishing a parallel conference in London (Hodgson, 2001, p. 3'495).

The following conference which was held at Paris in 1937 promoted a more social demography over the biological. According to Ramsden (2003):

«... all papers that included elements of Nazi radical doctrine were placed in a section with a paper by Franz Boas [1938], who argued that the 'naïve classification' of racial types was based not on scientific principles but on 'subjective attitudes'» (p. 557).

However, a new form of eugenics was promoted during this conference as social eugenics, term already used by Lorimer and Osborn (1934), and presented here by Osborn (1938). He agreed with Boas that differences in intelligence were in part determined by environment but as Ramsden (2003) says:

«Yet the measurement of intelligence was still relevant to the quality of individuals within the same groups, given the similarity of environmental influences on such individuals» (p. 558).

Such an attitude replaced the «propagandist eugenics» of the Thirties, during the post-war period. John Caldwell (1996) is quoted by Ramsden (2003), as having clearly explained how postwar demographers:

«... fought shy of the grander theory, and usually kept out of such battlegrounds as were offered by sociobiology, denying the element of eugenics in their past, and demanding ideas that promised the possibility of quantitative justification» (p. 329).

However, as previously said, social eugenics was now promoted by former American eugenicists, even though the eugenicist position was no 
longer mentioned explicitly. As Osborn already wrote in 1968; «Eugenic goals are most likely to be attained under a name other than eugenics» (p. 104).

For example, according to Ramsden (2003), Frederick Osborn, a wellknown promoter of eugenics in the previous pre-war period, co-founded the Population Council with John D. Rockefeller III in 1953, and was its president during the period 1957-1959:

«Osborn ensured that the Council supported limited research and training programs in the problems of 'population quality', first in medical genetics in the 1950 s and then in population genetics in the 60s» (Ramsden, 2003, p. 579).

As discussed by Connelly (2006), the early 1950s also marked the foundation of the International Planned Parenthood Federation (IPPF) in 1952, with Margaret Sanger as its first president - herself a supporter of eugenicist ideas. According to Connelly, Blacker, who later became administrative chairman of the IPPF:

«... worked with Osborn and won broad support for the goal of introducing 'family planning' to 'those who need it most'. This formulation elided the question whether the need was felt by the individuals themselves or by those who knew better - that is, the critical question of who would actually do the planning in 'family planning'» (Connelly, 2006, p. 221).

Later on, Salas, who was appointed the director of the UNFPA, acted without presenting its principles and procedures to the Economic and Social Councili ${ }^{13}$, consulting only countries favouring population control. In Connelly's words, this movement seems to have accomplished its goal «without having to answer to anyone in particular» (2006, p. 202).

To reach its political goals, the movement also used the methodology already presented in the first part of this paper: heritability analysis, and in particular research on IQ14. For example, Jensen (1969) estimated $h^{2}$ of IQ as 0.6 and $H^{2}$ as 0.8 to argue against the Head Start Programme for Black children in the USA. This permitted him to claim that as IQ has a high genetic component and is highly correlated with educational attainment, the programme would not result in higher achievement by Black children and money was being wasted. In the book The Bell Curve, Herrnstein and Murray (1994) argued that assortative mating and high heritabilities would lead to the emergence of a «cognitive elite». Lower

13. It is interesting to see how Sauvy (1969) pointed out that UNFPA «would act in the name of the United Nations without having to answer to them, free to dispense money to pharmaceutical companies and family planning associations» (Connelly, 2006, p. 228).

14. The argument in this section is taken from Vetta and Courgeau (2003). 
estimates of $h^{2}$ and $H^{2}$ of IQ at 0.36 and 0.48 obtained by Devlin et al. (1997) led McGue (1997) to state that:

«Devlin and colleagues' findings will lead to a reconsideration of the dire conclusions from the Bell Curve» (p. 417).

Still, even if IQ were indeed a genetic trait, the conclusions would not change: the lower estimates would merely impact the timing of the process.

Molecular genetics and genomics enabled further studies showing association between IQ and many single-nucleotide polymorphisms (SNPs) (Payton, 2009). However, more recent genome-wide association studies show that, as the title of the paper by Chabris et al. (2012) says: «Most reported genetic associations with general intelligence are probably false positives». As discussed in the next section, the legacy of Fisherian statistical inference and allowing, by convention, relatively high probability associated with false positives (e.g. 0.05), does not help. Chabris et al., (2012) conclude their study by saying:
«Our results add IQ to the list of phenotypes that must be approached with great caution when evaluating published molecular genetic associations. In our view, excitement over the value of behavioral and molecular genetic studies in the social sciences should be tempered - as it had been in the medical sciences - by an appreciation that for complex phenotypes, individual common genetic variants of the sort assayed by SNP microarrays are likely to have very small ef- fects» (p. 1'321).

The hope to find a clear signification to the heritability of IQ, with associated genes, may again be explained by the blind alley of heritability.

The use of GCTA techniques, mentioned in the section on the Idols of the Tribe, will not solve the problem either. As Turkheimer said on his blog15:

«If we were start a program tomorrow to take SNPs from newborns and predict their intelligence, we would do so at a level much worse than predicting from the parent's income, for example, never mind from their IQ».

As there are a very great number of other characteristics from the parents and from education given to the children that have great influence on their adult's IQ, the use of heritability or GCTA methods alone is not scientifically valid.

Eugenics and hereditarianism are always deeply anchored in present political thought, and to reject them with scientific arguments seems ve-

15. Quoted after: http://ericturkheimer.blogspot.fr, entry from 13 February 2013 (as of $1 / 04 / 2014$ ). 
ry difficult and even ineffective. Still, we argue that contemporary demography needs to make this effort - and be more aware of the false positives, which go undetected by the most commonly used statistical rituals - in order to steer clear from potentially very dangerous ideas that lack any scientific foundations.

\section{Idols of the Theatre (Idola Theatri)}

The last kind of Baconian idol has «immigrated into men's minds from the various dogmas of philosophies and also from wrong laws of demonstration» (Book One, XLIV). He characterizes them more precisely:

«But the Idols of the Theater are not innate, nor do they steal into the understanding secretly, but are plainly impressed and received into the mind from the playbooks of philosophical systems and the perverted rules of demonstration» (Book one, LVI).

He gave many examples of such idols coming from philosophy, religion and theology and showed that:

«There is taken from the material of philosophy either a great deal out of a few things, or a very little out of many things; so that on both sides philosophy ${ }^{16}$ is based on too narrow a foundation of experiment and natural history, an decides on the authority of too few cases» (Book one, LXII).

More recently such an approach based on a few cases of observations was developed corresponding to modern hermeneutics (the traditional hermeneutics, predominantly theological, is «the study of the methodological principles of interpretation ${ }^{17}$ ). This last form is what we will present and criticize here, first in its general application to social sciences and then in its application to demography ${ }^{18}$.

The modern hermeneutic approach was first introduced by Dilthey (1883), who made a distinction between comprehension (Verstehen) and explanation (Erklären). He recognizes that the natural sciences may

16. At the time of Bacon philosophy was a synonymous to science.

17. Merriam-Webster dictionary, http://www.merriam-webster.com/dictionary/ hermeneutics (as of 7/04/2014).

18. We want to stress here that we do not reject qualitative evidence in general: on the contrary, we think it has its valid place in scientific enquiry through providing context, information about underlying causal mechanisms, relationships between variables, knowledge a priori, etc. We argue, however, that this information should be - as any other - subjected to the rigours of the scientific method in order to lead to valid conclusions. 
be only explicative, while the social sciences need a more comprehensive approach. However, he never said that social sciences may be without explanation (Franck, 1994).

As argued by Kleining and Witt (2001), «the second impact of hermeneutics upon the social sciences occurred during the last third of the twentieth century» (p. 2), with philosophers like Gadamer, Habermas, Heidegger and Ricœur, and social scientists like the historian Skinner or the sociologist Giddens. Even though these authors may have some different points of view on hermeneutics, they all agree that:

«The next move a number of analytical philosophers have thus been prompted
to make is to appeal directly to the tradition of hermeneutics, as revived by Ga-
damer, Ricœur, and especially Habermas, and to argue for more interpretative
model of the natural, as well as the human sciences» (Skinner, 1975, p. 209).

Here Skinner posits that there are no universal truths in the sphere of natural and social sciences. Every situation is unique and should be viewed in its specific context to be properly understood. Similarly, Gadamer (1960) suggests that the Baconian idols are not distorting influences on our judgement, but are features of our experience that are irreducible to their teleological aspects, related to the questions of sense or purpose. These idols or prejudices (judgments made before the final examination of all moments that determine a thing), as Gadamer called them, are rejected by science, but are central to hermeneutic experience.

For a more detailed view on this theory, which is only briefly presented here, the book edited by Skinner on The return of grand theory in the human sciences (1985) will be a good reference.

However, even if this theory has been greeted positively by many reviewers and authors in different fields, it raises a number of general problems which overstep the differences between authors. We will not consider here the more philosophical problems of hermeneutics, but mainly those pertaining more generally to an hermeneutic view of social science and then to demography more specifically.

First, as hermeneutists do not recognize any value in the usual methods of social sciences, and even say they have no methods of their own for human sciences ${ }^{19}$ (Gadamer, 1960), they are unable to provide any guidance for the actual practice of the social sciences. In Gadamer's view, hermeneutics is not a prescriptive methodology, nor an epistemology, but rather an ontology (see also Mendelson, 1994), which is at first ap-

19. They often made a distinction between human sciences or humanities (philology, literary criticism, aesthetics, cultural history, etc.) and the other social sciences. 
proximation a study of what exists. This turns out to be a philosophical problem and as we said previously we will not consider it in this paper. However, Gadamer for example:

«... characterizes science as a mere 'amassing' of 'verified knowledge', whereas the human sciences deal with an entirely different dimension of human experience, the realm of truth» (Applebaum, 2011, p. 8).

He seems to have a very partial view of scientific research and does not offer a reflection on how in practice social or human research could be effectively conducted.

A second problem lies in the fact that hermeneutists consider that studied facts may be explained only by the particular ideas in vogue during a short period of time around their arrival. As Femia (1981) wrote about Skinner:

«[He] writes of the history of political thought as if it were merely a series of disconnected intellectual events. But if every historical utterance and action is a unique event, historical inquiry itself becomes impossible. The historian must, unavoidably, pursue analogies, make comparisons, identify regularities, and use general concepts. If all historical events are sui generis, then we cannot write history; we can only pile up documents» (p. 127).

For the hermeneutist, every fact - like every text - is unique and should be viewed in its specific context in order to be properly understood. Such an absence of connections between events occurring in different periods of time is at the core of hermeneutic thinking, and simultaneously cuts any links existing between events occurring in different times. This is not only true for history, but for every social science, for which different paradigms may have been created at different times in the past and are still used in the present. In this case there is no possibility, according to the hermeneutic perspective, of linking these approaches.

Another problem lies in the fact that written texts, which hermeneutists mainly consider, are from so many different authors and so often contradict each other that we may wonder how any real scientific result could be extracted from them. Even Skinner's seminal 1969 article on Meaning and understanding in the history of ideas was originally titled The unimportance of the great texts, a formulation which corresponds with the disrespectful aura of this article (Åsard, 1987). So, the main interest of the hermeneutists «should not be to explain, but only in the fullest detail to describe» (Skinner, 1966, p. 214).

Rather than continue this general criticism of hermeneutics, we will go now to its application to population science and demographic problems. Recently, Charbit (2010) has presented the emergence of population 
sciences following Skinner's approach. His work concentrates on contextualizing the texts he examined, taking into account different dimensions of each author's thought, such as population doctrine, political philosophy or economic theory. But he remains always entrenched in the period of time in which these authors lived, assuming that the links between different authors living in different periods of time are not really useful for the detailed understanding of a given author. As Morley (2012) said:

\begin{abstract}
"Charbit could usefully have focused more on the tradition of the reception of those writers, the role of their ideas in later debates even if interpreted in anachronistic and dubious ways, but his chosen approach of thorough-going contextualism closes off that possibility» (p. 347).
\end{abstract}

Charbit did not cross-examine the authors he studies enough to be able to give an original and new approach in the history of demographic ideas. For example, he was not able to understand the originality of Graunt's approach, only saying that he was using a «shop-Arithmetic», whereas he should have connected his thought to the general approach of science proposed by Bacon fifty year before, to the Bayesian approach of population problems by Laplace more than a century later and to the development of demography during the last one hundred years (Courgeau, 2013).

Similarly, a number of demographers consider that the usual approach of population problems is not sufficiently contextualized, and too analytical. While the former may be true in some cases, Petit and Charbit's (2012) charge against the so-called French school, which is in fact the usual scientific practice of demography in every country of the world since Graunt, develops a hermeneutic proposal.

First, we find here the main hermeneutic theme that the social sciences, contrary to the natural sciences, do not need an explanative approach but only a comprehensive one. Petit and Charbit stated:

\footnotetext{
«That the social sciences, as though affected by a nagging inferiority complex, continually seek to justify themselves in relation to natural sciences - and, more especially, of a belief in the supremacy of causality and determinism» (p. 330).
}

It seems surprising that the authors describe the social sciences as linked so closely to causality and determinism. From a long time now probability - mainly subjective as given by Bayes, but also objective as defined by Pascal - has been at the core of these sciences, and provides a rigorous language with which to talk about chance and which is also often opposed to causality. We will not discuss further here the use of these terms as that may lead to a more philosophical argument, but we 
think that with respect to contemporary demography these criticisms are misplaced.

Second, Petit and Charbit (2012) think that each society, even each social group within the same population, needs to be treated separately. The uniqueness of each text is replaced in the population field by the uniqueness of each considered group. They state that: «the reductive approach to social complexity implied by demography entail an especially stark disembodiment of reality» (p. 328). In this case, no generalization of their approach is possible and each study is confined into its own particularism. As observed by Little, $(2008$, p. 8), «it may appear that interpretations are self-confirming - an unhappy conclusion if we think that social explanations ought to have rational justification and empirical support».

Third, Petit and Charbit (2012) seem to neglect that the methods they criticize - by saying that «demography subsequently became increasingly sophisticated (and therefore increasingly withdrawn and isolated)» (p. 331) - have allowed demographers to invent new forms of analysis as required by their research objectives. For example, event history analysis allows us to analyse clinical trials in a new way on a small number of patients in order to save a great number of human lives (Andersen et al., 1993; Aalen et al., 2008).

Finally, Petit and Charbit (2012) suggest that a rapprochement of disciplines such as demography, economics, quantitative sociology, human geography, anthropology, history and more comprehensive forms of sociology is possible under an interdisciplinary area of research. As Gadamer wanted full and permanent cooperation between humanities, they wanted the same between social sciences. As appealing as it may sound, such a concept seems utopian and somewhat difficult to attain, as the fields of these social sciences are so different, going from statistical reasoning to historical contextualization. It seems to us, on the contrary, that we demographers have "to resist the temptation to spread ourselves too thinly; we must strive, on the contrary, to focus our research on the specific object of demography» (Courgeau, Franck, 2007, p. 39).

Hermeneutics is obviously not the only possible demographic Idol of the Theatre. Related problems can be seen also in attempts to uncritically transfer other tools specific to qualitative research - for example Glaser's and Strauss's (1967) «grounded theory» - to more quantitative 
fields of study, such as demography ${ }^{20}$. Here, one of the main problems is that in a scientific study of population-wide phenomena drawing conclusions on the basis of non-representative information will be almost surely biased.

Statistical methods have their challenges too. In particular, the problem of false positives in demography - incorrectly detecting patterns where there are none - may be widespread, predominantly owing to the proliferation of surveys and survey-based studies. Fisher's legacy in statistics is partly to blame as well. Not only does it entirely ignore the Type II errors associated with false negatives (missing the true patterns), but also has indirectly led to allowing, by mere convention, a relatively high probability of Type I errors associated with false positives (e.g. 0.05). In this context, Gigerenzer (2008) painted a picture of a «null ritual», whereby hypotheses are specified ex post after the statistical analysis has been conducted, and the reporting of p-values usually is limited to whether they are smaller than some threshold level, such as $0.1,0.05$ or 0.01 .

Fisherian inference, as opposed to the logicist or subjectivist (Bayesian) ones, the last one based on explicitly-defined prior beliefs, allows testing the probability of obtaining a given sample assuming that the hypothesis is true, but does not tell anything about the probability of the hypothesis. Unfortunately, through wide adoption of the «null ritual» to analysing survey-based information, demography may be exposed to the problem of false positives and false negatives. Especially in the era of «big data», automated data mining techniques - if used uncritically in conjunction with the «null ritual» and without following the necessary validation and calibration procedures - can easily lead to false discoveries $^{21}$.

\section{Conclusions}

The greatest successes of demography, and its most prominent areas of practical application for the public good, involve population-level statistical analysis and forecasting. The use of the inductive scientific method,

20. The authors are very grateful to a reviewer of The Quetelet Journal for drawing our attention to these issues. See also the following blog entry by Liili Abuladze: http://demotrends.wordpress.com/2013/06/24/a-case-for-quantitative-methods-indemography (as of 24/04/2014).

21. For a statistical discussion of data mining and problems with the associated true confidence levels, see e.g. Charemza and Deadman (1997). 
initiated four centuries ago by Bacon, is the best way to achieve this. As noted by Russell (1912): «we must either accept the inductive principle on the ground of its intrinsic evidence, or forgo all justification of our expectations about the future» (p.106). On the other hand, some demographers may be tempted to enrich demographic analysis by insights from arts, humanities and the world of politics, in order to deepen our understanding, aid explanation, increase societal relevance and help engage with the subject of the study: human populations and how they change.

In our view, the main challenge is to resist the Baconian idols - i.e. any biases and prejudices - in population analysis, and to keep sight of the main source of the "paradigmatic success» of demography (Morgan, Lynch, 2001), which is its empirical, scientific character. This does not imply that population sciences should become a complacent ivory tower or that we should not allow additional insights, influences and inspirations, insofar these are constantly submitted to the rigours of the inductive method as proposed by Bacon.

The overarching question remains: under which conditions can additional insights, influences and inspirations enrich the scientific study of human populations? These conditions consist, in our opinion, of continuously confronting new insights with the gathering of secure, relevant facts.

\section{Acknowledgements}

The first version of this paper was presented at Chaire Quetelet, Louvain-la-Neuve, in November 2013. The authors are grateful to Atam Vetta, two anonymous reviewers, and the editor of the Quetelet Journal, Philippe Bocquier, for their comments that helped us improve the earlier draft. All the remaining errors are ours. Jakub Bijak and Eric Silverman gratefully acknowledge the Engineering and Physical Sciences Research Council grant EP/H021698/1 «Care Life Cycle», funded within the «Complexity Science in the Real World» theme. All views and interpretations in this paper are those of the authors and should not be attributed to any institution with which they are affiliated. 


\section{References}

Aalen O. O., Borgan $\emptyset$., GJessing,H. K. (2008), Survival and Event History Analysis. A Process Point of View, New York, Springer, http://dx.doi.org/10.1007/978-0-38768560-1.

Andersen P. K., Borgan $\varnothing$., Gill R. D., Keiding N. (1993), Statistical Models Based on Counting Processes, New York, Springer, http://dx.doi.org/10.1007/978-1-46124348-9.

Applebaum M. H. (2011), «(Mis)Appropriation of Gadamer in Qualitative Research: A Husserlian Critique (Part I)», The Indo-Pacific Journal of Phenomenology, 11, pp. 1-17.

ÅsARD E. (1987), «Quentin Skinner and His Critics: Some Notes on a Methodological Debate», Statsvetenskaplig Tidskrift, 2, pp. 101-116.

Bacharach C. (2001), "Comment: The Puzzling Persistence of Postmodern Fertility Preferences», Population and Development Review, 27, pp. 332-338.

Bacon F. (1620), Novum Organum Scientiarum, London, J. Bill., (English translation: SPedding U., Ellis R. L., HeATH D. D. (1863), "The new Organon», The Works Vol. VIII, Boston, Taggard and Thompson.

Bijak J., Courgeau D., Silverman E., Franck R. (2014), "Quantifying Paradigm Change in Demography», Demographic Research, 30 (32), pp. 911-924, http://dx.doi.org/ 10.4054/DemRes.2014.30.32.

BoAs F. (1938), "Heredity and Environment», Congrès International de la Population, Paris, 1937, Vol. VUI, Problèmes Qualitatifs de la Population, Paris, Hermann et Cie., pp. 83-92.

CaldWell J. C. (1996), «Demography and Social Science», Population Studies, 50, pp. 305-333, http://dx.doi.org/10.1080/0032472031000149516.

Capron C., Vetta A. (2001), "Familial Studies: Genetic Inferences», International Encyclopedia of the Social and Behavioural Sciences, 8, pp. 5'259-5'265.

Chabris C. F., Hebert B. M., Benjamin D. J., Beauchamp J. P., Cesarini D., van der loos M. J. H. M., Johannesson M., Magnusson P. K. E., Lichtenstein P., Atwood C. S., Freese J., Hauser T. S., Hauser R. M., Christakis N. A., Laibson D. (2012), «Most Reported Genetic Associations with General Intelligence are Probably False Positives», Psychological Science, 23 (11), pp. 1'314-1'323.

Charbit Y. (2010), The Classical Foundations of Population Thought. From Plato to Quesnay. Dordrecht, Heidelberg, London, New York, Springer.

Charemza W., Deadman D. (1997), New Directions in Econometric Practice: General to Specific Modelling, Cointegration, and Vector Autoregression, Cheltenham, Edward Elgar. 
Charney E. (2012), "Behavior Genetics and Postgenomics with Discussion", Behavioral and Brain Sciences, 35, pp.331-410, http://dx.doi.org/10.1017/ S0140525X11002226.

Connelly M. (2006), «Seeing Beyond the State: The Population Control Movement and the Problem of Sovereignty", Past and Present, 193, pp. 197-233, http://dx. doi.org/10.1093/pastj/gtl016.

Courgeau D. (1972), «Les réseaux de relations entre personnes. Étude d'un milieu rural», Population, 27 (4-5), pp. 641-683, http://dx.doi.org/10.2307/1529338.

Courgeau D. (1985), «Interaction between Spatial Mobility, Family and Career LifeCycle: A French Survey», European Sociological Review, 1 (2), pp. 139-162.

Courgeau D. (2007), Multilevel Synthesis. From the group to the individual, Dordrecht, Springer.

Courgeau D. (2012), Probability and Social Science, Dordrecht, Heidelberg, London, New York, Springer, http://dx.doi.org/10.1007/978-94-007-2879-0.

Courgeau D. (2013), "La mesure dans les sciences de la population», Les Cahiers Philosophiques, 135, pp. 51-74, http://dx.doi.org/10.3917/caph.135.0051.

Courgeau D., Franck R. (2007), «Demography: A Fully Formed Science or a Science in the Making? An Outline Program», Population-E, 62 (1), pp. 39-45, http://dx.doi. org/10.3917/pope.701.0039.

Courgeau D., Vetta A. (2006), "Nature, culture et génétique du comportement», M. LORIAUX, É. VILQUIN (eds), Entre nature et culture: quelle(s) démographie(s) ? Chaire Quetelet 2002, Louvain-la-Neuve, Academia-Bruylant, pp. 85-96.

Devlin B., Daniels M., Roedre K. (1997), "The Heritability of IQ», Nature 388, pp. 468-470, http://dx.doi.org/10.1038/41319.

Dilthey W. (1883), Einleitung in die Geisteswissenschaften, Leipzig, Duncker \& Humblot, (English translation (1989): Introduction to the Human Sciences, Princeton, Princeton University Press).

DuCHEYNe S. (2005), «Bacon's Ideas and Newton's Practice of Induction», Philosophica, 76, pp. 115-128.

FEMIA J. V. (1981), «An Historicist Critique of 'Revisionist' Methods for Studying the History of Ideas», History and Theory 2, pp. 113-34, http://dx.doi.org/10.2307/ 2504763

FISHER R. A. (1918), "The Correlation between Relatives on the Supposition of Mendelian Inheritance», Transactions of the Royal Society of Edinburgh, 52, pp. 399433, http://dx.doi.org/10.1017/S0080456800012163.

Franck R. (ed) (1994), Faut-il chercher aux causes une raison ? L'explication causale dans les sciences humaines, Paris, Librairie Philosophique J. Vrin. 
Franck R. (ed) (2002), The Explanatory Power of Models. Bridging the Gap between Empirical and Theoretical Research in the Social Sciences, Boston, Dordrecht, London, Kluwer Academic Publishers.

GADAMER H.-G. (1960), Wahrheit und Methode: Grundzüge einer philosophischen Hermeneutik. Tübingen, Mohr, (English translation (1975: Truth and Method, London, Sheed \& Ward Ltd).

Galton D. J., Galton C. J. (1998), «Francis Galton and eugenics today», Journal of Medical Ethics, 24, pp. 99-105, http://dx.doi.org/10.1136/jme.24.2.99.

Galton F. (1865), «Hereditary Talent and Character», Macmillan's Magazine, 12, pp. 157-166, 318-327.

Galton F. (1869), Hereditary Genius: An Inquiry into its Laws and Consequences, London, Macmillan and Co, http://dx.doi.org/10.1037/13474-000.

Galton F. (1873), "The Relative Supplies from Town and Country Families, to the Populations of Future Generations», Journal of the Royal Statistical Society, 36, pp. 19-26.

Gatton F. (1883), Inquiries into Human Faculty and its Development, London, Macmillan and Co, http://dx.doi.org/10.1037/14178-000.

Galton F. (1904), "Eugenics: Its Definition, Scope, and Aims», American Journal of Sociology, 10 (1), pp. 1-25, http://dx.doi.org/10.1086/211280.

Gigerenzer G. (2008), Rationality for Mortals: How People Cope with Uncertainty, Oxford, Oxford University Press.

Glaser B. G., Strauss A. L. (1967), The Discovery of Grounded Theory: Strategies for Qualitative Research, New York, Aldine De Gruyter.

GotтuIEB G. (2001), "Genetics and Development», International Encyclopedia of the Social and Behavioural Sciences, 9, pp. 6'121-6'127.

Graunt J. (1662), Natural and Political Observations Made upon the Bills of Mortality, London, Tho. Roycroft.

Herrnstein R. J., MurRay C. (1994), The Bell Curve, London, The Free Press.

Hodgson D. (2001), «Demography: Twentieth-Century History», International Encyclopedia of the Social \& Behavioral Sciences, Amsterdam, Elsevier, pp. 3'493-3'498.

JACQUARD A. (1983), "Heritability: One Word, Three Concepts», Biometrics, 39, pp. 465-477, http://dx.doi.org/10.2307/2531017.

Jensen A. (1969), "How Much Can we Boost IQ and Scholastic Achievement?», Harvard Educational Review, 39, pp. 1-123.

JiNKS J. L., FUlKeR D. W. (1970), "Comparisons of the Biometrical Genetical, MAVA, and Classical Approaches to the Analysis of Human Behaviour", Psychological Bulletin, 73, pp. 311-349, http://dx.doi.org/10.1037/h0029135.

KLEINING G., WITT H. (2001), «Discovery as Basic Methodology of Qualitative and Quantitative Research», Forum: Qualitative Social Research, 2 (1), art. 16. 
LATOUR B. (1998), "How to Be Iconophilic in Art, Science and Religion», C. Jones, P. Galison, A. SLAton (eds), Picturing Science, Producing Art, London, Routledge, pp. 418-440.

LITTLE D. (2008), What Is Hermeneutic Explanation?, Research gateway, http:// www.changingsociety.org/.

LORIMER F., OsboRn F. (1934), Dynamics of Population: Social and Biological Significance of Changing Birth- Rates in the United States, New York, The Macmillan Company.

LUSH J. L. (1936), "Genetic Aspects of the Danish System of Progeny-Testing Swine», Journal of the Lowa Agricultural Experiment Station Result Bulletin, 204, pp. 109195.

LYOTARD J.-F. (1979), La condition postmoderne : rapport sur le savoir, Paris, Les Editions de Minuit, (English translation (1984): The Postmodern Condition: A Report on Knowledge, Minneapolis, The University of Minnesota Press).

Manolo T. A. (2013), "Bringing Genome-Wide Association Findings into Clinical Use», Nature Reviews Genetics, 14, pp.540-556, http://dx.doi.org/10.1038/ $\operatorname{nrg} 3523$.

McGue M. (1997), "The Democracy of the Genes», Nature, 388, pp.417-418, http://dx.doi.org/10.1038/41199.

Mendelson J. (1979), "The Habermas-Gadamer Debate», New German Critique, 18 (Autumn), pp. 44-73, http://dx.doi.org/10.2307/487850.

MILL J. S. (1843), A System of Logic, Ratiocinate and Inductive, Being a Connected View of the Principles of Evidence, and the Methods of Scientific Investigation, London, John W. Parker.

Miller W. B., BARd D. E., PASta D. J., Rodgers J. L. (2010), «Biodemographic Modelling of the Links between Fertility Motivation and Fertility Outcomes in the NLSY79», Demography, 47 (2), pp. 393-414, http://dx.doi.org/10.1353/dem.0.0107.

Moors H., Palomba R. (1995), Population, Family and Welfare: A Comparative Survey of European Attitudes, Vol. I., Oxford, Clarendon Press.

Morgan S. P., King R. S. (2001), "Why Have Children in the 21st Century», European Journal of Population, 17, pp.3-20, http://dx.doi.org/10.1023/A: 1010784028474.

MoRgAn S. P., LYNCH S. M. (2001), "Success and Future of Demography. The Role of Data and Methods", Annals of the New York Academy of Sciences, 954, pp. 35-51, http://dx.doi.org/10.1111/j.1749-6632.2001.tb02745.x.

Mortey N. (2012), "Book Review of 'The Classical Foundations of Population Thought' by Yves Charbit», Population Studies, 66 (3), pp. 347-348, http://dx.doi. org/10.1080/00324728.2012.719716.

Newton I. (1687), Philosophiæ naturalis principia mathematica, Londini, Societatis Reginae. 
OsBoRn F. (1938), "The Application of Measures of Quality», Congrès International de la Population, Paris, 1937, Vol. IV, Problèmes qualitatifs de la population, Paris, Hermann et Cie.

OsBoRn F. (1968), The Future of Human Heredity: An Introduction to Eugenics in Modern Society, New York, Waybright and Talley.

PAscal B. (1654), Celeberimmæ mathesos academiæ Pariensi, Paris, Académie Parisienne.

PAsCal B. (1922), Les lettres de Blaise Pascal accompagnées de lettres de ses correspondants, Paris, Les Éditions G. Grès.

PAyton A. (2009), "The Impact of Genetic Research on our Understanding of Normal Cognitive Ageing», Neuropsychology Review, 19, pp. 451-477, http://dx.doi. org/10.1007/s11065-009-9116-z.

Petit V., Charbit Y. (2012), "The French School of Demography: Conceptualizing Demographic Analysis», Population and Development Review, 38 (Suppl.), pp. 322333, http://dx.doi.org/10.1111/j.1728-4457.2013.00567.x.

Plomin R., Defries J. C., Knopik V. S., Neiderhiser J. M. (2012), Behavioral Genetics. 6th Edition, New York, Worth Publishers.

RAMSDEN E. (2003), "Social Demography and Eugenics in the Interwar United States», Population and Development Review, 29 (4), pp. 547-593, http://dx.doi. org/10.1111/j.1728-4457.2003.00547.x.

Riley N. E., McCaRThy J. (2003), Demography in the Age of the Postmodern, Cambridge, Cambridge University Press, http://dx.doi.org/10.1017/ CB09781139165204.

Rodgers J. L., Kohler H. P., KyviK K. O., Christensen K. (2001a), «Behaviour Genetic Modelling of Human Fertility», Demography, 38, pp. 29-42, http://dx.doi.org/10. 1353/dem.2001.0009.

Rodgers J. L., Hughes K., Kohler H. P., Christensen K., Doughty D., Rowe D. C., Miller W. B. (2001b), «Genetic Influence Helps Explain Variations in Human Fertility: Evidence from Recent Behavioural and Molecular Genetic Studies», Current Directions in Psychological Science, 10 (5), pp. 184-188, http://dx.doi.org/10.1111/1467-8721. 00145.

Russell B. (1912), The Problems of Philosophy, London, Williams \& Norgate.

SARKAR, S. (1998), Genetics and Reductionism, Cambridge, Cambridge University Press, http://dx.doi.org/10.1017/CBO9781139173216.

Sauvy A. (1969), Projet de création de poste d'un commissaire des Nations Unies à la Population, Centre des archives contemporaines, Fontainebleau, Fonds Alfred Sauvy, versement 20000115, Article 7.

SKINNER Q. (1966), «The Limits of Historical Explanations», Philosophy, 157, pp. 199215, http://dx.doi.org/10.1017/S003181910005868X. 
SKINNER Q. (1969), "Meaning and Understanding in the History of Ideas», History and Theory, 1, pp. 3-53, http://dx.doi.org/10.2307/2504188.

SKINNER Q. (1975), "Hermeneutics and the Role of History», New Literary History, 7 (1), pp. 209-232, http://dx.doi.org/10.2307/468286.

SKINNER Q. (ed) (1985), The Return of Grand Theory in the Human Sciences, Cambridge, Cambridge University Press.

SoKAL A. D. (1996), «Transgressing the Boundaries: Towards a Transformative Hermeneutics of Quantum Gravity», Social Text, 46/47, pp. 217-252, http://dx.doi.org/ 10.2307/466856.

SokAl A. D., BRICMont J. (1997), Impostures intellectuelles, Paris, Odile Jacob, (English translation: Fashionable Nonsense, Postmodern Intellectuals' Abuse of Science, New York, Picador).

Soloway R. A. (1990), Demography and Degeneration. Eugenics and the Declining Birthrate in Twentieth-Century Britain, Chapel Hill, The University of North-Carolina Press.

VAN DE KAA D. J. (1998), «Postmodern Fertility Preferences: From Changing Value Orientation to new Behaviour», Working papers in Demography No. 74, The Australian National University, Published later (2001) with some changes in Population and Development Review, 27, pp. 290-331.

Van Dongen J., Slagboom P. E., Draisma H. H. M., Martin N. G., Boomsma D. I. (2012), "The Continuing Value of Twin Studies in the Omics Era», Nature Reviews Genetics, 13, pp. 640-653, http://dx.doi.org/10.1038/nrg3243.

VetTA A. (1976), «Corrections to Fisher's Correlations between Relatives and Environmental Effects», Nature, 263, pp.316-317, http://dx.doi.org/10.1038/ $263316 a 0$.

Vetta A., Courgeau D. (2003), "Demographic Behaviour and Behaviour Genetics», Population E, 58 (4-5), pp. 401-428, («Comportement démographique et génétique du comportement», Population F, 58 (4-5), pp. 457-488), http://dx.doi.org/10. 3917/popu.304.0457.

Visscher P. M., Hill W. G., Wray N. R. (2008), "Heritability in the Genomics Era Concepts and Misconceptions», Nature Reviews: Genetics, 9 (4), pp. 255-266, http://dx.doi.org/10.1038/nrg2322.

Watson J. D., CRICK F. H. C. (1953), "Molecular Structure of Nucleic Acids. A Structure for Deoxyribose Nucleic acid», Nature, 4'356, pp. 737-738.

Yang J. Y., Lee S. H., Goddard M. E., Visscher P. M. (2011), «GCTA: A tool for Genome-Wide Complex Trait Analysis», The American Journal of Human Genetics, 88, pp. 76-82, http://dx.doi.org/10.1016/j.ajhg.2010.11.011. 